Annals of Warsaw University of Life Sciences - SGGW

Land Reclamation No 47 (1), 2015: 55-67

(Ann. Warsaw Univ. Life Sci. - SGGW, Land Reclam. 47 (1), 2015)

\title{
Comparison of the predicted insulation of clothing in Toruń and Koniczynka in the years 1998-2012*
}

\author{
ANDRZEJ ARAŹNY, JOANNA USCKA-KOWALKOWSKA, MAREK KEJNA \\ Department of Meteorology and Climatology, Faculty of Earth Sciences \\ Nicolaus Copernicus University in Torun
}

\begin{abstract}
Comparison of the predicted insulation of clothing in Torun and Koniczynka in the years 1998-2012. This paper compares the predicted insulation of clothing (Iclp) in Torun and Koniczynka, presented using a scale of evaluation of thermal environment proposed by B. Krawczyk (2000). The annual mean value of predicted insulation of clothing in urban areas of Torun was equal to $1.0 \mathrm{clo}$, which was 0.1 less than in the agricultural area of Koniczynka. The influence of atmospheric circulation on the Iclp index was also analysed. The study used the circulation types as classified by Niedźwiedź (1981) in the Catalogue of atmospheric circulation for the Bydgoszcz-Toruń region (Przybylak and Maszewski 2009, 2013). The frequency of occurrence of individual circulation types was examined along with their influence on the predicted insulation of clothing in different seasons of the year and in an annual course. During the year, the highest mean value of Iclp (1.4 clo in Koniczynka) corresponded to cyclonic situations with northerly advection, whereas the lowest value ( 0.8 clo in Torun and Koniczynka) was observed for the anticyclonic wedge.
\end{abstract}

Key words: biometeorological conditions, predicted insulation of clothing, atmospheric circulation, Toruń, Koniczynka

\section{INTRODUCTION}

Clothing provides the most basic protection from unfavourable influence of weather. In changeable climate condi- tions the equilibrium between the amount of heat received and lost by the human body can be maintained thanks to thermoregulatory reactions, but also thanks to adequately chosen clothes (cf. Krawczyk 1993, Yan and Oliver 1996). A great number of problems with adaptation to unstable weather conditions results from the use of unsuitable clothing. The index of predicted insulation of clothing (Iclp) enables the determination of thermal insulation properties of clothing (in clo units) required to strike the thermal balance of the body in given meteorological conditions (Kuchcik et al. 2013). Nowadays, clothing can be optimally adapted to the conditions of any environment and physical activity in order to provide man with thermal comfort.

The observations were conducted in Toruń, a city situated in the Torun valley, and its suburban area in the village of Koniczynka, situated in the Chełmno Lakeland. The area, according to the regional division proposed by Romer (1949), falls into the climate category of the Land of Great Valleys, whereas

\footnotetext{
* This paper is a part of the NCN research project N N306 723040 - "The Diversity of the local climate in Torun depending on natural and anthropogenic factors" and studies conducted within the framework of the Integrated Monitoring of the Natural Environment.
} 
in the agricultural and climatic classification of Gumiński (1948) it belongs to the $7^{\text {th }}$ central district. Woś (1996) drew attention to the area's climatic peculiarity by identifying a separate Chelmno-Torun climate region there. The lowland part of Poland, where the analysed stations are situated, has a 'weak stimulating bioclimate' (Kozłowska-Szczęsna et al. 1997). It is an area with the smallest number of thermally uncomfortable days as compared with the rest of Poland.

The climatic conditions of the Chełmno Lakeland, and of Torun and Koniczynka (Central Poland) in particular, have been the subject of a number of studies. A detailed list of these works can be found, for example, in the publications of Kejna et al. (2004), Kejna (2006) or Wójcik and Marciniak (2006). As far as bioclimatic studies of the area are concerned, the article of Araźny et al.
(2007) is a useful reference, providing an analysis of the cooling power of air.

The purpose of this paper is to compare the predicted insulation of clothing in Torun and at Koniczynka in the years 1998-2012. Additionally, the influence of atmospheric circulation on the values of Iclp in the analysed area is addressed.

\section{MATERIAL AND METHODS}

The study applies to the station of the Institute of Meteorology and Water Management in Torun Wrzosy and to the station of the Integrated Monitoring of the Natural Environment at Koniczynka, and concerns the period of 1998-2012. The two stations have distinct features. The meteorological station in Torun Wrzosy (Fig. 1) is situated in right part of the Torun valley $\left(\varphi=53^{\circ} 02^{\prime} \mathrm{N}, \lambda=\right.$ $18^{\circ} 35^{\prime} \mathrm{E}, \mathrm{h}=69 \mathrm{~m}$ a.s.1.), some $5 \mathrm{~km}$ from the river Vistula. The station at Koniczynka (Fig. 2) is situated in the

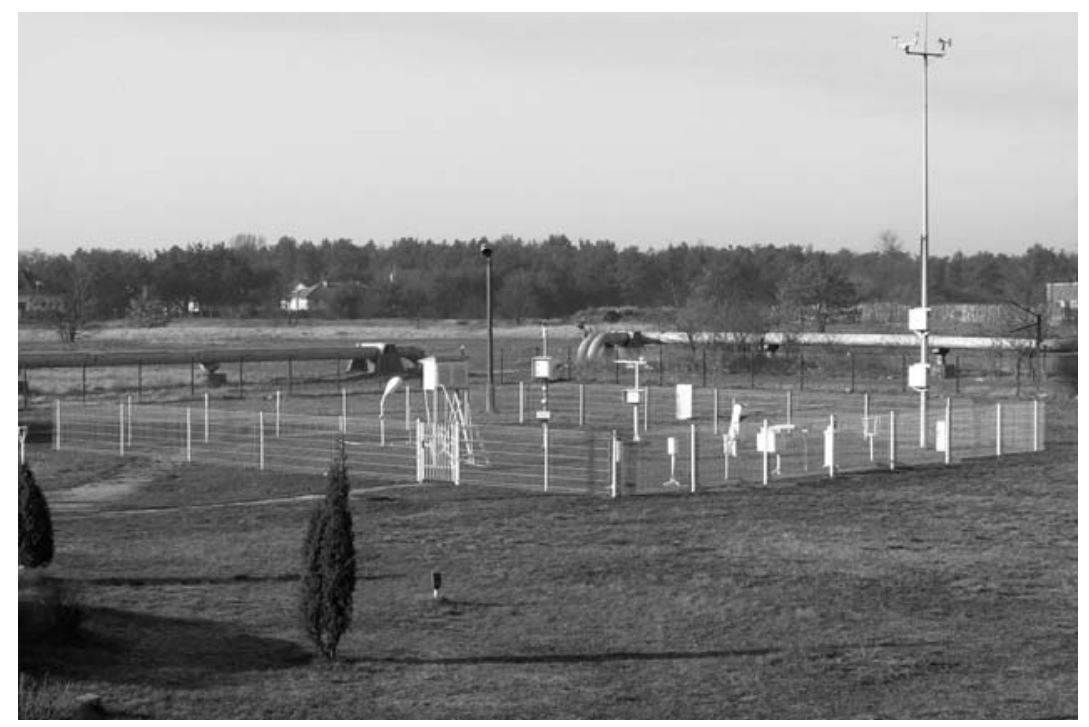

FIGURE 1. The station of the Institute of Meteorology and Water Management in the Torun district of Wrzosy (photo by A. Araźny) 


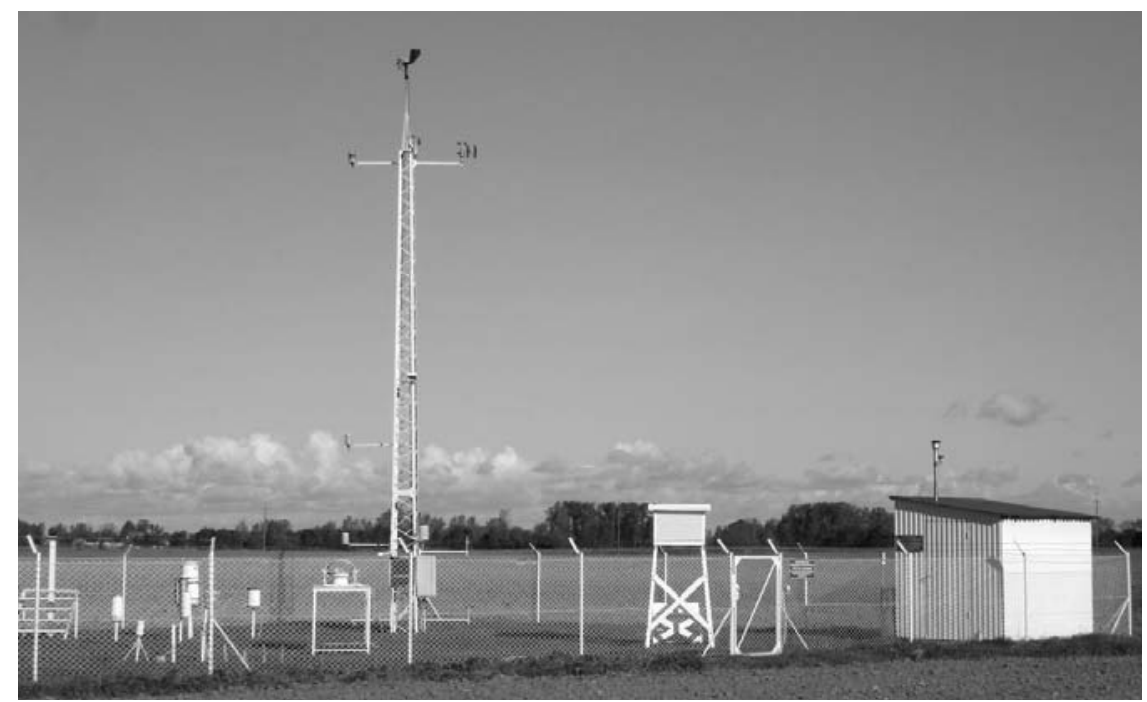

FIGURE 2. The base station of the Integrated Monitoring of the Natural Environment at Koniczynka near Toruń (photo by M. Kejna)

Chelmno Lakeland $\left(\varphi=53^{\circ} 07^{\prime} \mathrm{N}, \lambda=\right.$ $=18^{\circ} 42^{\prime} \mathrm{E}, \mathrm{h}=84 \mathrm{~m}$ a.s.l.), north of Torun on the young glacial flat moraine plain formed during the last glaciation and has been extensively cultivated (Wójcik and Marciniak 1996).

In order to calculate the Iclp index fixed-time values (12:00 UTC) of air temperature and wind speed were used. To determine the wind conditions and to calculate the Iclp in Torun and at Koniczynka, the wind speed at the level of measurement (the anemometer height) was reduced to a height of $1.2 \mathrm{~m}$ a.g.l. (i.e. the level of a human torso) using Milewski's formula (1960).

The predicted insulation of clothing (Iclp) was determined on the basis of the values of air temperature and wind speed using the following formula (Błażejczyk 2004):

$$
\begin{aligned}
& \text { Iclp }=0.082 \cdot[91.4-(1.8 \cdot T+32)] / \\
& /(0.01724 \cdot M)-1 /\left(0.61+1.9 \cdot v^{0.5}\right)
\end{aligned}
$$

where:

$t$ - air temperature $\left({ }^{\circ} \mathrm{C}\right)$, $v$ - wind speed $\left(\mathrm{m} \cdot \mathrm{s}^{-1}\right)$,

$M$ - metabolism $\left(\mathrm{W} \cdot \mathrm{m}^{-2}\right)$.

For the calculation of $I c l p$, the value of metabolism was assumed at $135 \mathrm{~W} \cdot \mathrm{m}^{-2}$ which corresponds to moderate physical activity (such as walking at $4 \mathrm{~km} \cdot \mathrm{h}^{-1}$ ). Then the predicted insulation of clothing was determined (in clo) using Bioklima 2.6 software package (Błażejczyk 2013).

On the basis of the value of Iclp the thermal environments of Torun and Koniczynka were evaluated using the scale proposed by Krawczyk (2000): very warm $(<0.30 \mathrm{clo})$, warm $(0.31-$ -0.80 clo), neutral (0.81-1.20 clo), cool (1.21-2.00 clo), cold (2.01-3.00 clo), very cold (3.01-4.00 clo), arctic cold (>4.00 clo). The thermal insulation properties of selected seasonal clothing are shown in Table 1. 
TABLE 1. Basic thermal insulation of clothing ensembles (Icl) to be used outdoor (Krawczyk 1993)

\begin{tabular}{|c|c|c|c|}
\hline \multirow{2}{*}{ Type } & \multirow{2}{*}{ Clothing description } & \multicolumn{2}{|c|}{ Icl } \\
\hline & & clo & $\mathrm{K} \cdot \mathrm{m}^{2} \cdot \mathrm{W}^{-1}$ \\
\hline 1 & Summer clothing & & \\
\hline 1.1 & Very light & & \\
\hline & a) shorts & 0.1 & 0.016 \\
\hline & b) shorts, T-shirt & 0.3 & 0.045 \\
\hline 1.2 & Light & & \\
\hline & a) long trousers, $\mathrm{T}$-shirt & 0.5 & 0.078 \\
\hline & b) robe with short sleeves & 0.5 & 0.078 \\
\hline & c) light working clothing & 0.6 & 0.093 \\
\hline & d) light military uniform & 0.7 & 0.108 \\
\hline & e) light sport's wear & 0.9 & 0.140 \\
\hline 1.3 & Oridinary & & \\
\hline & a) wool men's suit & 1.0 & 0.155 \\
\hline & b) wool women's suit & 1.0 & 0.155 \\
\hline & c) typical working clothing & 1.0 & 0.155 \\
\hline 2 & Transient season's clothing & & \\
\hline & a) men's suit shirt, coat & 1.5 & 0.232 \\
\hline & b) women's suit, blouse, coat & 1.5 & 0.232 \\
\hline & c) typical working clothing, coat & 1.5 & 0.232 \\
\hline & d) warm working clothing & 1.5 & 0.232 \\
\hline & e) similar to type $2 \mathrm{a} .2 \mathrm{~b}+$ hat, scarf, gloves & 2.5 & 0.388 \\
\hline 3 & Winter clothing & & \\
\hline 3.1 & $\begin{array}{l}\text { Light } \\
\quad \text { similar to type } 1.3+\text { warm coat, cap, sharf, gloves }\end{array}$ & 3.0 & 0.465 \\
\hline 3.2 & $\begin{array}{l}\text { Oridinary } \\
\quad \text { similar to type } 3.1 \times \text { warm underwear, boots }\end{array}$ & 3.5 & 0.542 \\
\hline 3.3 & $\begin{array}{l}\text { Arctic } \\
\text { thermoinsulative underwear, polar (sweter), heavy coat, } \\
\text { cap, gloves, boots }\end{array}$ & $>4.0$ & $>0.620$ \\
\hline
\end{tabular}

The study also presents the influence of atmospheric circulation on the predicted insulation of clothing, using the circulation types identified by Niedźwiedź (1981) in the Catalogue of atmospheric circulation for the Bydgoszcz-Torun region (Przybylak and Maszewski 2009, 2013). For the classification, the type of barometric centre was defined ( $\mathrm{a}-$ anticyclone, c-cyclone) as well as the direction of advection using the 8-point wind rose. Also, the following situations were identified: the anticyclonic centre (Ca), the anticyclonic wedge $(\mathrm{Ka})$, the cyclonic centre $(\mathrm{Cc})$ and the cyclonic trough $(\mathrm{Bc})$, whereas any other situations were marked with an ' $X$ '. In this paper, the frequency of occurrence of individual circulations types was analysed along with their influence on Iclp in seasonal, annual and multi-annual courses. 
RESULTS AND DISCUSSION

\section{General meteorological conditions}

Changes in air temperature have a significant influence on the physical wellbeing of people staying outdoors for a long time (Kozłowska-Szczęsna et al. 1997). The mean annual air temperature at 12:00 UTC in Torun in the years 1998-2012 was $12.0^{\circ} \mathrm{C}$ and was $0.2^{\circ} \mathrm{C}$ higher than the one determined for Koniczynka (Table 2). The lowest mean monthly temperature in the reference
The movement of air is essential in the process of heat exchange between a human body and the environment. A high wind at low temperatures, or a hardly noticeable breeze at high temperatures may both disturb the heat balance of a human body (Kuchcik et al. 2013). The mean annual wind speed at a level of the human torso $(1.2 \mathrm{~m})$ at 12:00 UTC in Torun was $2.3 \mathrm{~m} \cdot \mathrm{s}^{-1}$ (Table 3 ). At Koniczynka, which is a village in a flat and open moraine plain, the mean wind speed was $0.6 \mathrm{~m} \cdot \mathrm{s}^{-1}$ higher than

TABLE 2. Mean $\left(T_{m}\right)$, the highest $\left(T_{h}\right)$ and the lowest $\left(T_{1}\right)$ values of air temperature $\left({ }^{\circ} \mathrm{C}\right)$ at $12: 00 \mathrm{UTC}$ in Torun and at Koniczynka in the years 1998-2012

\begin{tabular}{|c|r|r|r|r|r|r|r|r|r|r|r|r|r|}
\hline $\begin{array}{l}\text { Para- } \\
\text { meter }\end{array}$ & Jan & Feb & March & April & May & June & July & Aug & Sep & Oct & Nov & Dec & Year \\
\hline \multicolumn{10}{|c|}{ Toruń } \\
\hline$T_{m}$ & 0.2 & 1.6 & 6.3 & 13.5 & 18.3 & 20.8 & 23.1 & 22.6 & 18.4 & 12.0 & 5.7 & 1.1 & 12.0 \\
\hline$T_{h}$ & 12.2 & 13.7 & 20.2 & 30.2 & 30.9 & 33.7 & 35.8 & 34.3 & 30.4 & 24.0 & 15.6 & 12.4 & 35.8 \\
\hline$T_{l}$ & -19.7 & -14.3 & -3.3 & 0.8 & 6.4 & 10.6 & 12.0 & 12.0 & 8.1 & 0.3 & -9.7 & -12.5 & -19.7 \\
\hline \multicolumn{10}{|c|}{ Koniczynka } \\
\hline$T_{m}$ & -0.1 & 1.1 & 5.8 & 13.2 & 18.0 & 20.4 & 22.8 & 22.5 & 18.2 & 11.8 & 5.3 & 0.5 & 11.8 \\
\hline$T_{h}$ & 10.4 & 11.8 & 19.8 & 30.1 & 29.8 & 34.2 & 35.2 & 33.8 & 30.7 & 23.3 & 15.4 & 11.0 & 35.2 \\
\hline$T_{l}$ & -20.7 & -13.5 & -4.9 & 0.6 & 6.5 & 9.8 & 11.8 & 12.4 & 7.8 & -0.5 & -10.6 & -13.2 & -20.7 \\
\hline
\end{tabular}

period occurred in January $\left(-0.1^{\circ} \mathrm{C}\right.$ at Koniczynka and $0.2^{\circ} \mathrm{C}$ in Toruń), whereas the highest one was recorded in July $\left(23.1^{\circ} \mathrm{C}\right.$ in Torun and $22.8^{\circ} \mathrm{C}$ at Koniczynka). The range of midday (at 12:00 UTC) air temperatures in both places was similar (approx. $56^{\circ} \mathrm{C}$ ): from -19.7 to $35.8^{\circ} \mathrm{C}$ in Torun and from -20.7 to $35.2^{\circ} \mathrm{C}$ at Koniczynka (Table 2). its counterpart in Torun. The greatest monthly mean values of the wind speed were observed from January to April. High speed winds, particularly if gusty, provide unfavourable mechanical stimuli for man. Throughout the year maximum values of wind speed at Koniczynka are a few $\mathrm{m} \cdot \mathrm{s}^{-1}$ higher than in Toruń (Table 3). 
TABLE 3. Mean $\left(V_{m}\right)$ and the highest $\left(V_{h}\right)$ values of wind speed $\left(\mathrm{m} \cdot \mathrm{s}^{-1}\right)$ at $1.2 \mathrm{~m}$ a.g.1. at 12:00 UTC in Torun and at Koniczynka in the years 1998-2012

\begin{tabular}{|c|c|c|c|c|c|c|c|c|c|c|c|c|c|}
\hline $\begin{array}{c}\text { Para- } \\
\text { meter }\end{array}$ & Jan & Feb & March & April & May & June & July & Aug & Sep & Oct & Nov & Dec & Year \\
\hline \multicolumn{10}{|c|}{ Toruń } \\
\hline$V_{m}$ & 2.3 & 2.4 & 2.5 & 2.5 & 2.3 & 2.3 & 2.2 & 2.2 & 2.2 & 2.3 & 2.1 & 2.1 & 2.3 \\
\hline$V_{h}$ & 5.9 & 5.9 & 6.5 & 5.9 & 5.2 & 5.9 & 4.6 & 5.2 & 5.2 & 5.2 & 7.9 & 5.2 & 7.9 \\
\hline \multicolumn{10}{|c|}{ Koniczynka } \\
\hline$V_{m}$ & 3.1 & 3.2 & 3.4 & 3.0 & 2.7 & 2.8 & 2.7 & 2.7 & 2.7 & 2.8 & 2.7 & 2.8 & 2.9 \\
\hline$V_{h}$ & 11.6 & 11.6 & 10.3 & 9.6 & 8.3 & 8.3 & 8.3 & 10.9 & 8.3 & 8.2 & 11.1 & 10.3 & 11.6 \\
\hline
\end{tabular}

\section{Predicted insulation of clothing}

The predicted insulation index (Iclp) was used to evaluate the bioclimates of Torun and Koniczynka from the point of view of demand for suitable clothing that would provide man with thermal comfort. The annual mean value of Iclp in Torun was 1.0 clo, which was 0.1 clo lower than at Koniczynka (Table 4). In both analysed sites mean values indicate a neutral thermal environment. In spring, summer and autumn, seasonal mean values of Iclp are the same in both sites (1.0, 0.4 and 1.0 clo, respectively). In winter, however, the thermal insulation index of clothing should be higher at Koniczynka (1.8 clo) than in Toruń ( 1.7 clo). Iclp demonstrates considerable variability in annual courses of both day-by-day (Fig. 3) and year-by-year values (Fig. 4). In Poland the longest multi-annual changes of Iclp was calculated in Kraków (Błażejczyk et al. 2003).

TABLE 4. Mean (Iclpm), the highest (Iclph) and the lowest (Iclpl) values of the predicted insulation of clothing (clo) at a moderate physical activity $\left(M=135 \mathrm{~W} \cdot \mathrm{m}^{-2}\right)$ at 12:00 UTC for Toruń and Koniczynka in the years 1998-2012

\begin{tabular}{|c|c|c|c|c|c|c|c|c|c|c|c|c|c|}
\hline $\begin{array}{l}\text { Para- } \\
\text { meter }\end{array}$ & Jan & Feb & March & April & May & June & July & Aug & Sep & Oct & Nov & Dec & Year \\
\hline \multicolumn{14}{|c|}{ Toruń } \\
\hline$I c l p_{m}$ & 1.8 & 1.7 & 1.4 & 0.9 & 0.6 & 0.5 & 0.3 & 0.4 & 0.6 & 1.0 & 1.4 & 1.7 & 1.0 \\
\hline$I c l p_{h}$ & 3.0 & 2.6 & 2.0 & 1.8 & 1.4 & 1.2 & 1.1 & 1.1 & 1.3 & 1.8 & 2.3 & 2.7 & 3.0 \\
\hline$I c l p_{l}$ & 1.1 & 0.9 & 0.5 & 0.0 & 0.0 & 0.0 & 0.0 & 0.0 & 0.0 & 0.1 & 0.8 & 1.0 & 0.0 \\
\hline \multicolumn{14}{|c|}{ Koniczynka } \\
\hline$I c l p_{m}$ & 1.8 & 1.7 & 1.5 & 1.0 & 0.7 & 0.5 & 0.4 & 0.4 & 0.6 & 1.1 & 1.4 & 1.7 & 1.1 \\
\hline$I c l p_{h}$ & 3.1 & 2.6 & 2.2 & 1.9 & 1.5 & 1.2 & 1.1 & 1.1 & 1.3 & 1.9 & 2.5 & 2.7 & 3.1 \\
\hline Iclp & 1.0 & 0.8 & 0.5 & 0.0 & 0.0 & 0.0 & 0.0 & 0.0 & 0.0 & 0.2 & 0.7 & 0.9 & 0.0 \\
\hline
\end{tabular}




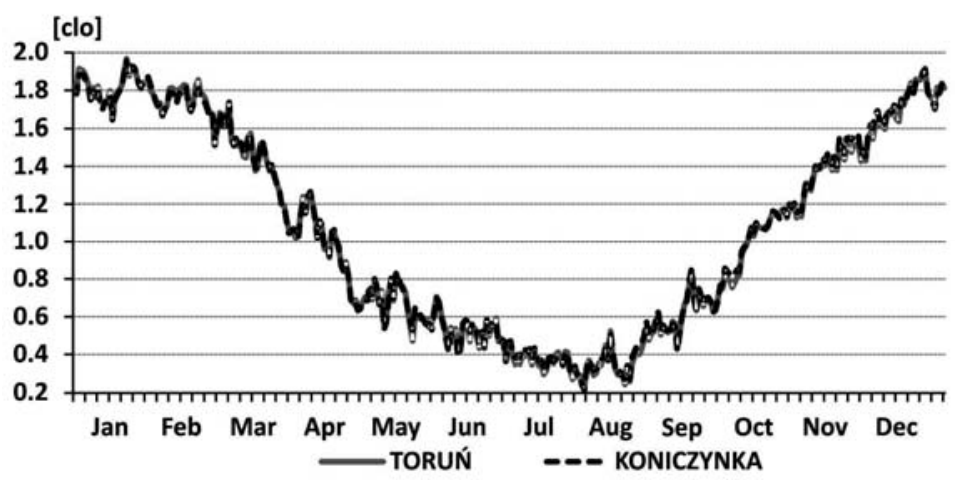

FIGURE 3. Annual course of the Iclp index (clo) at a moderate physical activity for Torun and Koniczynka in the years 1998-2012, according to the values at 12:00 UTC

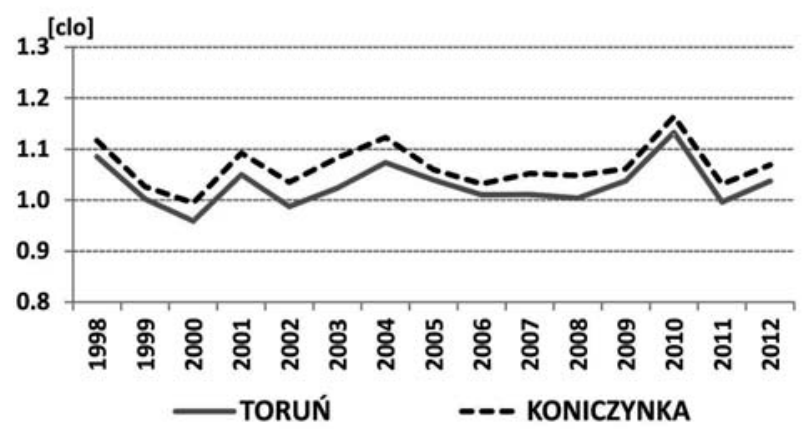

FIGURE 4. Year-by-year course of mean values of the Iclp index (clo) at a moderate physical activity for Torun and Koniczynka in the years 1998-2012

In the period 1901-2000 was observed important trends -0.11 clo per 100 years for Iclp.

Throughout the year, in Torun and at Koniczynka, the optimal outfits required for man in motion - considering its thermal insulation properties - ranged from summer to winter clothing (Table 4, Fig. 3). In the analysed sites, light and very light clothing $(<1.0$ clo) should be worn for about 180 days in the warm half of the year (i.e. from April to October in Torun, and from April to September at Koniczynka). For about 80 days, from June to August only light summer clothes $(<0.5$ clo $)$ should be usually worn. In March and October, the summer clothing should be supplemented with accessories that increase its heat insulating properties $(1.0-1.5 \mathrm{clo})$. On the annual basis, this kind of clothing is used in the analysed sites for about 88 days. Transitional season clothing (1.5-2.5 clo) is necessary to maintain the heat balance for approximately 94 days in Toruń and 102 days at Koniczynka, whereas light winter clothing should be worn from November until February. 
One should remember, however, that in order to provide a man standing outdoors with a similar thermal comfort clothing should have twice as high insulation properties as for a man moving. This results from the fact that heat generated by metabolism when standing still decreases from approx. 135 to $70 \mathrm{~W} \cdot \mathrm{m}^{-2}$, which is almost $100 \%$ less as compared with the heat produced by the body of a walking man.

In winter season, e.g. in January, "cool" and "cold" thermal environment conditions clearly prevailed (Fig. 5), making up $70 \%$ (Koniczynka) to $72 \%$ (Toruń) and 27\% (Toruń) to 29\% (Koniczynka) cases within the study area, respectively. In summer months, such as July, the most frequent thermal conditions observed for a man walking at $4 \mathrm{~km} \cdot \mathrm{h}^{-1}$ outdoors were either "warm" or "very warm". These made up about $90 \%$ of all cases (Fig. 5).

Table 5 contains the differences in the frequency of occurrence of thermal environment in the different classes of Iclp between Torun and Koniczynka in the analysed period. It was found that in

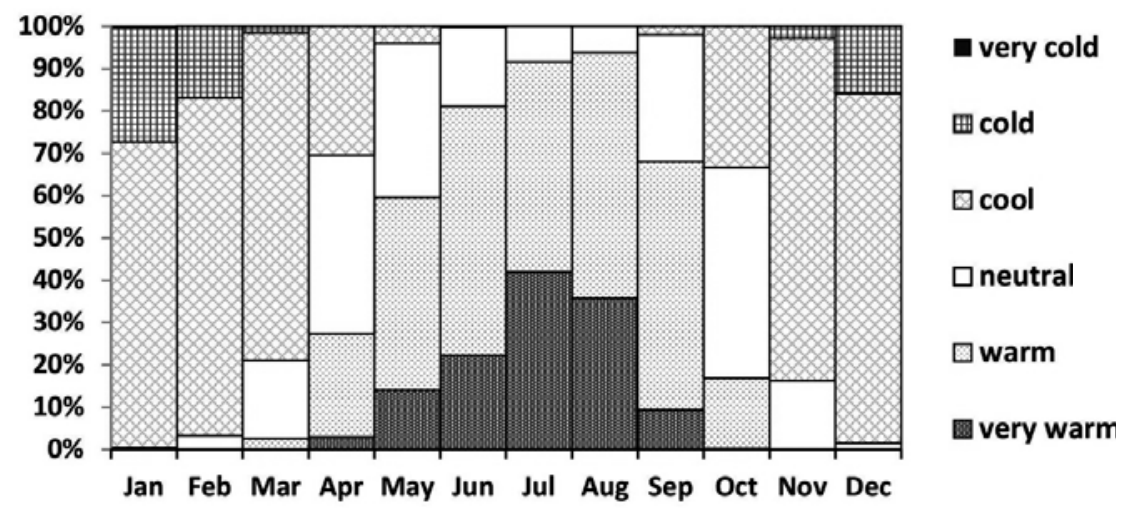

FIGURE 5. Annual course of the frequency of occurrence (\%) of different thermal environment classes for the predicted insulation index of clothing (clo) at a moderate physical activity in Torun in the years $1998-2012$

TABLE 5. Annual course of the difference in the frequency of occurrence (\%) of different thermal environmental classes (very warm, warm etc.) for the Iclp (clo) at a moderate physical activity, between Torun and Koniczynka in the years 1998-2012

\begin{tabular}{|l|c|c|r|r|r|r|r|r|r|r|r|c|}
\hline $\begin{array}{l}\text { Thermal } \\
\text { feeling }\end{array}$ & Jan & Feb & March & April & May & June & July & Aug & Sep & Oct & Nov & Dec \\
\hline Very warm & \multicolumn{1}{|c}{.} &. &. & 0.2 & -1.1 & 0.7 & 4.7 & -0.2 & -0.7 & 0.0 &. &. \\
\hline Warm & \multicolumn{1}{c|}{$\cdot$} &. & 0.0 & 2.2 & 5.4 & 3.1 & -2.4 & 2.8 & 6.7 & 0.9 & -0.4 &. \\
\hline Neutral & 0.0 & 1.2 & 3.4 & 1.3 & -2.4 & -2.7 & -2.4 & -2.6 & -4.9 & 4.3 & 1.6 & 0.4 \\
\hline Cool & 1.9 & 4.0 & -1.3 & -3.8 & -1.9 & -1.1 &. &. & -1.1 & -5.2 & -1.6 & 4.5 \\
\hline Cold & -1.9 & -5.2 & -2.2 &. &. &. &. &. &. &. & 0.4 & -4.9 \\
\hline Very cold & 0.0 &. &. &. &. &. &. &. &. &. &. &. \\
\hline
\end{tabular}


all categories of thermal conditions conducive to the cooling of the human body were more frequent at Koniczynka than in the urban area of Torun.

\section{The influence of atmospheric} circulation on the predicted insulation of clothing

Specific types of atmospheric circulation and correlated advections of air masses with different physical properties determine the values of weather elements which affect the amount of heat ex- change between the human body and its environment (Krawczyk 1993). Stable anticyclonic weather is the least biologically active, whereas cyclonic situations provide particularly powerful stimuli (Błażejczyk 2004, Kozłowska-Szczęsna et al. 2004).

The frequency of atmospheric circulation types demonstrates a variability in annual, seasonal and multi-annual courses (Fig. 6). On average, in the years 1998-2012, cyclonic types prevailed in the analysed area, making up $50.2 \%$ of
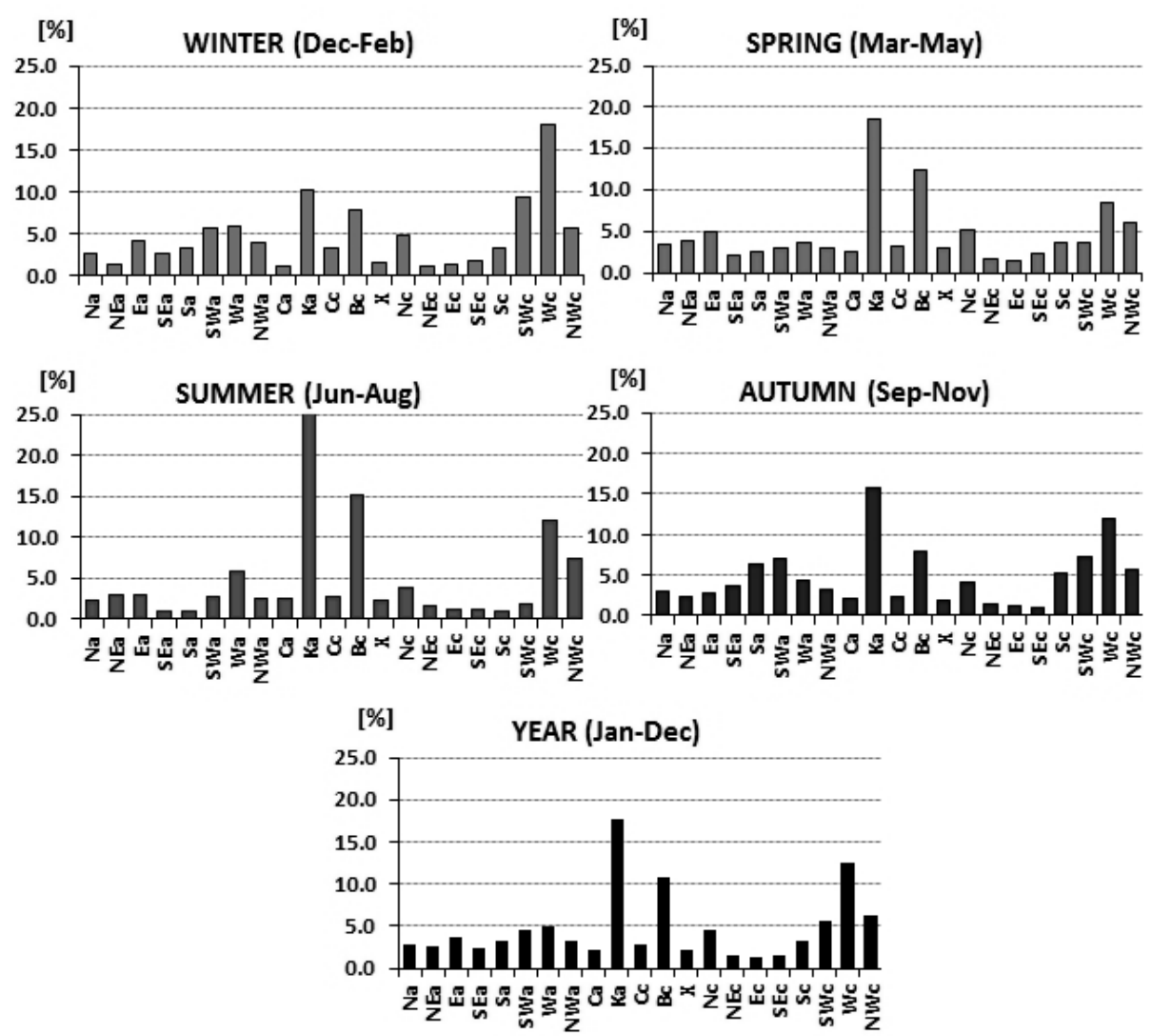

FIGURE 6. Average frequency of atmospheric circulation types according to the classification of Niedźwiedź in the Bydgoszcz-Torun region in individual seasons and in the whole year in the years $1998-2012$ 
observed situations. On the other hand, anticyclonic types constituted $47.5 \%$ of all cases. The rest of the days were determined as an "X" type.

In an annual course, the direction of advection changes, just as the frequency of occurrence of individual circulation types. In the analysed period, the Ka circulation type revealed the greatest frequency (17.6\%), along with $\mathrm{Wc}$ and $\mathrm{Bc}$ situations: 12.6 and $10.8 \%$ of the days, respectively (Fig. 6). The anticyclonic wedge was most frequent in summer $(25.6 \%)$ and the least frequent in winter $(10.3 \%)$, when the advection of air masses with westerly cyclonic types prevails, with the dominant Wc type (17.9\%). Circulation types $\mathrm{Ka}, \mathrm{Bc}$ and $\mathrm{Wc}$ occur more than a half of all summer days.

The advection of air masses from different directions when cyclonic or anticyclonic situations occur considerably affects the predicted insulation properties of clothing for the given area. The average demand for heat insulation of clothing of a man performing a moderate physical activity in the case of the cyclonic macro-type was 0.1 and 0.2 clo higher (at Koniczynka and in Torun, respectively) than with an anticyclonic macro type (observed differences 0.1 and 0.2 clo are statistically significant at the level of 0.05).

The relationship between the predicted insulation of clothing and the atmospheric circulation in Torun and at Koniczynka is similar in all seasons of the year, except for winter. In spring, summer and autumn, a better-than-average thermal insulation of clothing (about $0.3-0.4$ clo) is necessary in the case of cyclonic synoptic situations with the inflow of air masses from the north-eastern sector. In winter, extra layers of clothing are also required in the case of anticyclonic synoptic situations with air masses inflowing from the north-east (Fig. 7). In individual seasons, less insulating clothes can be worn when air masses flow from the S-W sector (the type of the barometric system is not important). Throughout the year, the highest mean value of Iclp occurred with Nc situations (1.4 clo at Koniczynka), whereas the lowest value was recorded for Ka type (0.8 clo in both stations) - Figure 7.

The highest values of Iclp around midday were recorded with different synoptic situations in individual seasons of the year, however some of them were more conducive to the occurrence of anomalies (e.g. Ea, NEa, Sea, Ec or $\mathrm{Nc}$ ) than the other. The highest value of Iclp (at a moderate physical activity $\mathrm{M}=135 \mathrm{~W} \cdot \mathrm{m}^{-2}$ ) around midday in Torun was observed on 22 January 2006 with Ea situation (3.1 clo at Koniczynka and 3.0 clo in Toruń).

\section{CONCLUSIONS}

As a result of the meteorological conditions prevailing in Poland the value of the predicted insulation index for clothing ranges from about 0.5 clo in the summer months to about 1.5-2.0 clo in winter (e.g. Krawczyk 1993, Kuchcik et al. 2013). Similar values at midday hours were confirmed in Torun and at Koniczynka. The mean annual value of the Iclp index at a moderate physical activity was 1.0 clo in the urban area of Torun. In the open farmland of 


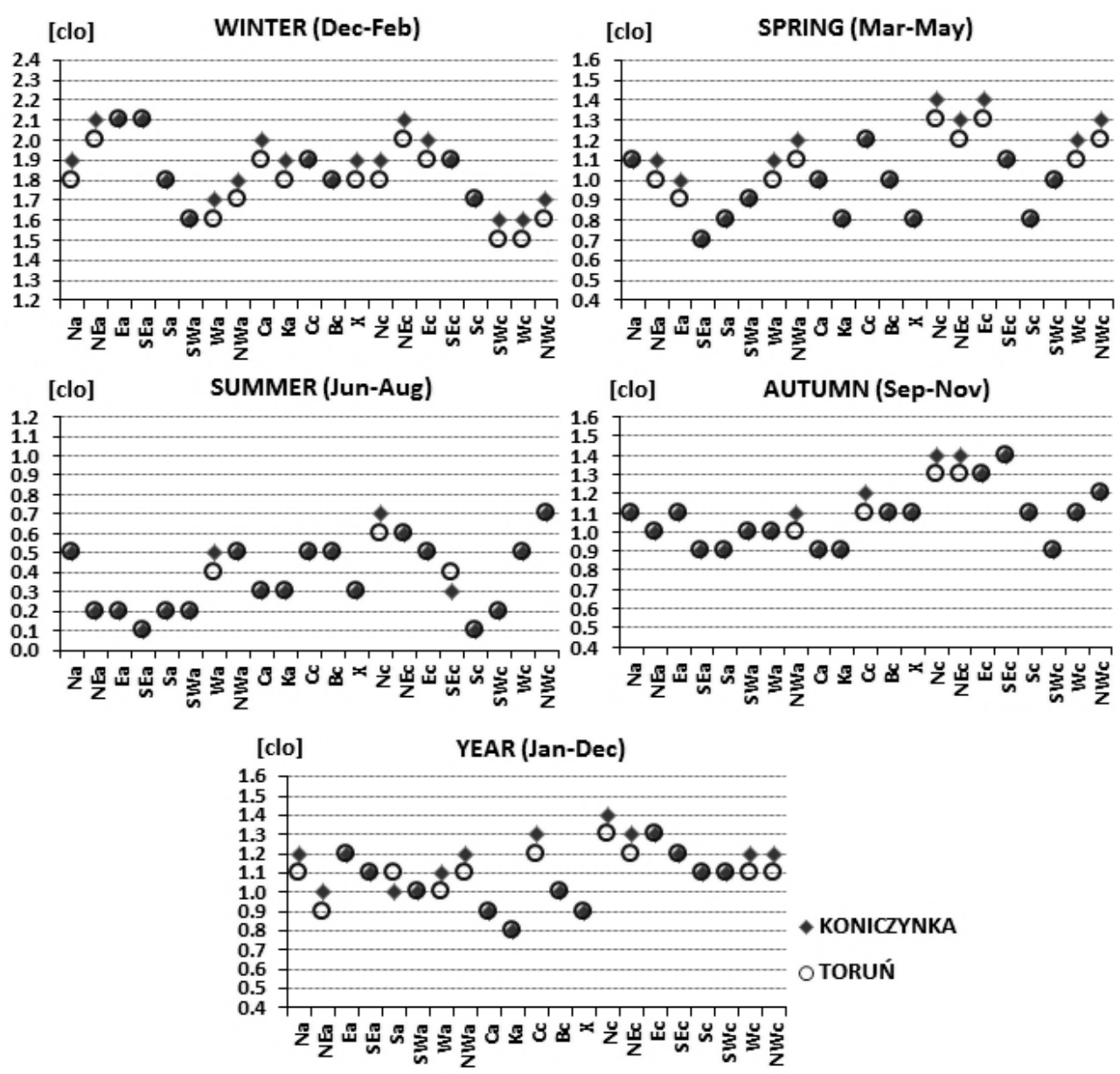

FIGURE 7. Mean values of the Iclp index (in clo) for different atmospheric circulation types in Torun and at Koniczynka at a moderate physical activity in individual seasons and in the whole year in the years 1998-2012

Koniczynka the required thermal insulation index of clothing should be a little higher (by 0.1 clo). The difference is due to the winter weather conditions which involve a 0.1 clo higher value of the Iclp index of clothing at Koniczynka, as compared with Torun. In the period from spring to autumn, the values of Iclp are similar in both stations. On av- erage, during the whole year extra layers of clothing are most often required in the case of cyclonic synoptic situations with northerly and easterly advection of air masses. Summing up, the prevailing thermal sensation across the studied area is "cool". Standard summer clothing or transitional season clothing is recommended throughout most of the year. 


\section{REFERENCES}

ARAŹNY A., USCKA-KOWALKOWSKA J., KEJNA M. 2007: Wielkość ochładzająca powietrza w Koniczynce w latach 1998-2006 [Cooling power of the air in Koniczynka in the period 1998-2006]. In: A. Kostrzewski, A. Andrzejewska (Eds). Zintegrowany Monitoring Środowiska Przyrodniczego, Program Zintegrowanego Monitoringu Środowiska Przyrodniczego a zadania ochrony obszarów Natura 2000. Biblioteka Monitoringu Środowiska, Warszawa, 91-100 (Engl. Summ.).

BŁAŻEJCZYK K. 2004: Bioklimatyczne uwarunkowania rekreacji i turystyki w Polsce [Bioclimatic principles of recreation and tourism in Poland]. Wyd. IGiPZ PAN, Prace Geograficzne 192, Warszawa (Engl. Summ.).

BŁAŻEJCZYK K. 2013: Bioklima 2.6, software package. www.igipz.pan.pl/ geoekoklimat/ blaz/bioklima.htm.

BŁAŻEJCZYK K., TWARDOSZ R., KUNET A. 2003: Zmienność warunków biotermicznych w Krakowie w XX wieku na tle wahań cyrkulacji atmosferycznej [Changes of bioclimatic conditions in Cracow in the XX century against the fluctuations of atmospheric circulation]. In: K. Błażejczyk, B. Krawczyk, M. Kuchcik (Eds). Postępy w badaniach klimatycznych i bioklimatycznych. Prace Geograficzne 188. PAN IGiPZ, Warszawa, 233-246.

GUMIŃSKI R. 1948: Próba wydzielenia dzielnic rolniczo-klimatycznych w Polsce [An attempt to separation districts of agro-climatic conditions in Poland]. Przeglad Meteorologiczny $i$ Hydrologiczny I, 1 (in Polish).

KEJNA M. 2006: Stacja Bazowa Koniczynka [Base station in Koniczynka] In: A. Kostrzewski (red.), Stan, przemiany i funkcjonowanie geoekosystemów Polski w latach 1994-2004 na podstawie Zintegrowanego Monitoringu Środowiska Przyrodniczego. Biblioteka Monitoringu Środowiska, Warszawa, 137-172 (in Polish).

KEJNA M., USCKA J., WÓJCIK G., MARCINIAK K. 2004: Warunki klimatyczne w Koniczynce (Pojezierze Chełmińskie) w latach 1994-2002 [Climate conditions at Ko- niczynka (Chelmno Lakeland) in the years 1994-2002]. In: M. Kejna, J. Uscka (Eds). Zintegrowany Monitoring Środowiska Przyrodniczego. Funkcjonowanie i monitoring geoekosystemów w warunkach narastającej antropopresji. Biblioteka Monitoringu Środowiska, 131-146 (Engl. Summ.).

KOZŁOWSKA-SZCZĘSNA T., BŁAŻEJCZYK K., KRAWCZYK B. 1997: Bioklimatologia człowieka [Human bioclimatology]. Monografie IGiPZ PAN, 1, Warszawa (Engl. Summ.).

KOZŁOWSKA-SZCZECNA T., KRAWCZYK B., KRAWCZYK B. 2004: Wpływ środowiska atmosferycznego na zdrowie i samopoczucie człowieka [The influence of atmospheric environment on the human health and well being]. Monografie IGiPZ PAN, 4, Warszawa (Engl. Summ.).

KRAWCZYK B. 1993: Typologia i ocena bioklimatu Polski na podstawie bilansu cieplnego ciała człowieka [The typology and evaluation of the bioclimate of Poland on the basis of the human body heat balance]. Wyd. IGiPZ PAN, Prace Geograficzne, 160, Warszawa (Engl. Summ.).

KRAWCZYK B. 2000: Izolacyjność cieplna odzieży jako wskaźnik oceny warunków biotermicznych [Effective clothing insulation index as a basis of evaluation of thermal conditions]. Balneologia Polska 62 (3-4), 105-111 (Engl. Summ.).

KUCHCIK M., BŁAŻEJCZYK K., SZMYD J., MILEWSKI P., BŁAŻEJCZYK A., BARANOWSKI J. 2013: Potencjał leczniczy klimatu Polski [The therapeutic potential of the Polish climate]. Wydawnictwo Sedno i IGiPZ PAN, Warszawa (Engl. Summ.).

MILEWSKIJ W.J. 1960: Effektiwnyje tiempieratury na jewropejskoj tierritorii SSSR. In: Woprosy prikładnoj klimatołogii. Leningrad (in Russian).

NIEDŹWIEDŹ T. 1981: Sytuacje synoptyczne i ich wpływ na zróżnicowanie przestrzenne wybranych elementów klimatu w dorzeczu górnej Wisły [Synoptic situations and their influence on spatial differentiation of the selected climate elements in the Upper Vistula Basin]. Rozprawy habilitacyjne UJ, Kraków (Engl. Summ.). 
PRZYBYLAK R., MASZEWSKI R. 2009: Zmienność cyrkulacji atmosferycznej $\mathrm{W}$ Regionie Bydgosko-Toruńskim w latach 1881-2005 [Atmospheric circulation variability in the Bydgoszcz-Torun Region in the period 1881-2005]. Acta Agrophysica 14 (2), 427-448 (Engl. Summ.).

PRZYBYLAK R., MASZEWSKI R. 2013: Catalogue of atmospheric circulation for the Region Bydgoszcz-Torun in the period 1881-2012 (computer file). Katedra Meteorologii i Klimatologii UMK, Toruń.

ROMER E. 1949: Okresy gospodarcze w Polsce [Farming periods in Poland]. Prace Wrock. Tow. Nauk. ser. B, 20 (in Polish).

YAN Y.Y., OLIVER J.E. 1996: The Clo: A Utilitarian Unit To Measure Weather/Climate Comfort. Int. J. Climatol. 16 (9), 1045-1056.

WÓJCIK G., MARCINIAK K. (Eds) 1996: Zintegrowany Monitoring Środowiska Przyrodniczego - Stacja Bazowa Koniczynka [Integrated Monitoring of the Natural Environment Basic Station Koniczynka]. Biblioteka Monitoringu Środowiska, Warszawa-Toruń (Engl. Summ.).

WÓJCIK G., MARCINIAK K. 2006: Klimat [Climate]. In: L. Andrzejewski, P. Weckwerth, S. Burak (Eds). Torun i jego okolice: monografia przyrodnicza. Wydawnictwo Uniwersytetu Mikołaja Kopernika, Toruń, 99-128 (Engl. Summ.).

WOŚ A. 1996: Zarys klimatu Polski [An outline of the climate of the Poland]. Wydawnictwo Naukowe Bogucki, Poznań (Engl. Summ.).

Streszczenie: Porównanie przewidywanej termoizolacyjności odzieży w Toruniu i Koniczynce w latach 1988-2012. Celem pracy jest porówna- nie przewidywanej termoizolacyjności odzieży (Iclp) w Toruniu i Koniczynce. Opracowanie wykonano dla Stacji IMGW Toruń Wrzosy oraz dla Stacji Zintegrowanego Monitoringu Środowiska Przyrodniczego w Koniczynce dla okresu 1998-2012. Każda z badanych stacji charakteryzuje się indywidualnymi cechami. Przewidywaną termoizolacyjności odzieży przedstawiono według skali oceny środowiska termicznego zaproponowanej przez B. Krawczyk (2000). Zbadano również wpływ cyrkulacji atmosferycznej na wskaźnik Iclp. W badaniach wykorzystano typy cyrkulacji wg klasyfikacji T. Niedźwiedzia (1981) z Katalogu cyrkulacji atmosferycznej dla Regionu Bydgosko-Toruńskiego (Przybylak i Maszewski 2009, 2013). Przeanalizowano częstość występowania poszczególnych typów cyrkulacji oraz ich wpływ na przewidywaną termoizolacyjność odzieży w poszczególnych porach roku i przebiegu rocznym.

Stowa kluczowe: warunki biometeorologiczne, przewidywana termoizolacyjność odzieży, cyrkulacja atmosferyczna, Toruń, Koniczynka

\section{MS. received May 2014}

\section{Authors' addresses:}

Andrzej Araźny, Joanna Uscka-Kowalska, Marek Kejna

Katedra Meteorologii i Klimatologii

Wydział Nauk o Ziemi

Uniwersytet Mikołaja Kopernika w Toruniu ul. Lwowska 1, 87-100 Toruń

Poland

e-mail: andy@umk.pl,joannauk@umk.pl, makej@umk.pl 